\title{
Contribution to the knowledge of Pyrenean stoneflies (Insecta : Plecoptera)
}

\author{
P. Zwick ${ }^{1}$ \\ G. Vinçon ${ }^{2}$
}

Keywords : mountain stream fauna, Plecoptera, new species, France, Spain, Andorra.

Several new species of Plecoptera (Leuctra hexacanthoides, L. berthelemyi, L. thomasi, Protonemura culmenis, $P$. canigolensis) collected in the Pyrenees of France, Andorra, and Spain are described and illustrated. Protonemura brevistyla (Ris) and P. montana Kimmins are recorded from the Pyrenees for the first time.

Contribution à la connaissance des Plécoptères pyrénéens (Insecta : Plecoptera)

Mots clés : faune des cours d'eau de montagne, Plecoptera, espèces nouvelles, France, Espagne, Andorre.

Plusieurs espèces nouvelles de Plécoptères (Leuctra hexacantoides, L. berthelemyi, L. thomasi, Protonemura culmenis, $P$. canigolensis) récoltées dans les Pyrénées françaises, andorannes et espagnoles sont décrites et illustrées. Protonemura brevistyla (Ris) et $P$. montana Kimmins sont signalés des Pyrénées pour la première fois.

\section{Introduction}

In the last decades, detailed studies of Plecoptera have been undertaken at various sites along the Pyrenean mountain chain, especially in water courses at high altitudes (see Berthélemy 1966, Vinçon 1987, as well as references to earlier papers therein). In this context, we recognize the special significance of our regretted colleague, the late Professor C. Berthélemy, to whom we owe the stimulus for research leading to the discovery of new or poorly known species reported in this paper. In particular, C. Berthélemy supervised the thesis of G. Vinçon. A complete list of Plecoptera identified during that study is available (Vinçon 1987). In the present paper, we describe new species contained in the same material, and record $P$. montana Kimmins and $P$. brevistyla (Ris), species with interesting wide distributions that were previously unknown from the Pyrenees. An analysis of polymorphism and biogeography of some Leuctra, especially of L. kempnyi, is under preparation.

1. Limnologische Flussstation Schlitz des Max-Planck-Instituts für Limnologie, P.O.B. 260, D-36105 Schlitz, Federal Republic of Germany.

2. 38 bis, rue du Drac, F-38000 Grenoble, France.
The material used in this study is preserved in alcohol. Specimens are shared between the collections of the authors, type material of all new species being presently deposited in coll. Zwick, Limnologische Flussstation at Schlitz, Germany.

\section{Descriptions and Records}

\subsection{Leuctra hexacanthoides Zwick \& Vinçon sp.n.}

Material : Spain, Prov. Pamplona, Vallée de la Nive d'Arnéguy : Rio Luzane Valcarlos, $1000 \mathrm{~m}, 29.8 .1986$ : male holotype, 11 ơ , 8 \% paratypes. - Additional material : same locality and date, $16 \sigma^{\circ}, 18 \%$. Rio Luzane Valcarlos, $500 \mathrm{~m}, 1$ \% , 29.8.86. France, Dépt. PyrénéesAtlantiques : Vallée d'Ossau : Gave de Brousset, $1170 \mathrm{~m}$, 3 o , 5 \%, 29.9.84; 7 o , 20 \& , 21.9.85 ; torrent de Pombie, $1350 \mathrm{~m}, 1$, 29.9 .84 ; Gave de Bious, $1417 \mathrm{~m}, 1$ 우, 11.11 .84 ; Source d'Iscoo, $850 \mathrm{~m}, 1$ o , 19.12 .92 ; torrent de Canceigt, $495 \mathrm{~m}, 1$ \% , 28.8.84. Vallée du Vert d'Arète : Ruisseau de Chousse, $1100 \mathrm{~m}, 3$ \& , 7.8.87. Vallée du Gave de Larreau : Ruisseau d'Olhadoko, 1300 m, 9 o*, 15 \&, 29.8.86. Vallée du Rio Irati : tributary to Rio Iratico Erreka, location called " Sourzay », $1200 \mathrm{~m}, 4$ O , 5 \%, 6.8.87. Vallée de la Nive de Béhérobie : Ruisseau d'Esterenguibel, $1100 \mathrm{~m}, 3 \circ$, 6.8 .87 ; Ruisseau d'Inzarasquijko, $1000 \mathrm{~m}, 1$ o*, 6.8 .87 ; Nive de Béhérobie, $900 \mathrm{~m}$, $1 \%, 6.8 .87$. Vallée de la Nive des Aldudes: Ruisseau d'Hayra, $1000 \mathrm{~m}, 1$ ơ 1 \%, 29.8.86. 
A fairly large Leuctra, front wing $6.5-9.0 \mathrm{~mm}$ long. Slender, pronotum elongate, longer than wide. Pilosity normal, very inconspicuous. Uniformly light to middle brown, except female tergites 1 - 8 whitish, each with a transverse row of 4 minute brown spots, tergite 2 with strong medially divided antecosta.

- Male (Figs 1a-d) : Tergites VI-VIII each with a pair of obliquely raised appendages. Sclerite of tergite VI reduced to a very narrow strip behind the antecosta, with two short blackish appendages separated by little more than twice their width ; remainder of tergite pale, finely setose. Tergite VII similar but appendages separated by about three times their width. Tergite VIII again similar but antecosta interrupted between widely separate small appendages ; posteromedian portion of tergite occupied by large diffuse square spot with some longer setation and a slightly raised transverse fold. Tergite IX with narrow ante- costa medially connected to a large bell-shaped spot with pale central line. Tergite $X$ deeply excavated. Epiproct consisting of a narrow rod and a vaguely sclerotized square spot near its distal end. Cerci normal. Paraprocts with triangular, medially setose outer lobes terminating in elongate rods with hooked tip ; some similar fine setae in front of paraprocts on perianal membrane. Median paraproct lobes more slender in posterior view, their tip more rounded, blunt in side view. Vesicle of sternite IX very long, pedunculate.

- Female (Fig. 1e) : Sternite VIII with sclerotized anterior patches serving muscle attachment. Posteriorly, sternite VIII forms a simple gently arched subgenital plate with shallow median notch and regularly rounded simple lobes. Posterior portion of plate less sclerotized than anterior, fairly pale. Spermatheca normal, with delicate, smooth thread-like sclerite arranged in the normal pattern.
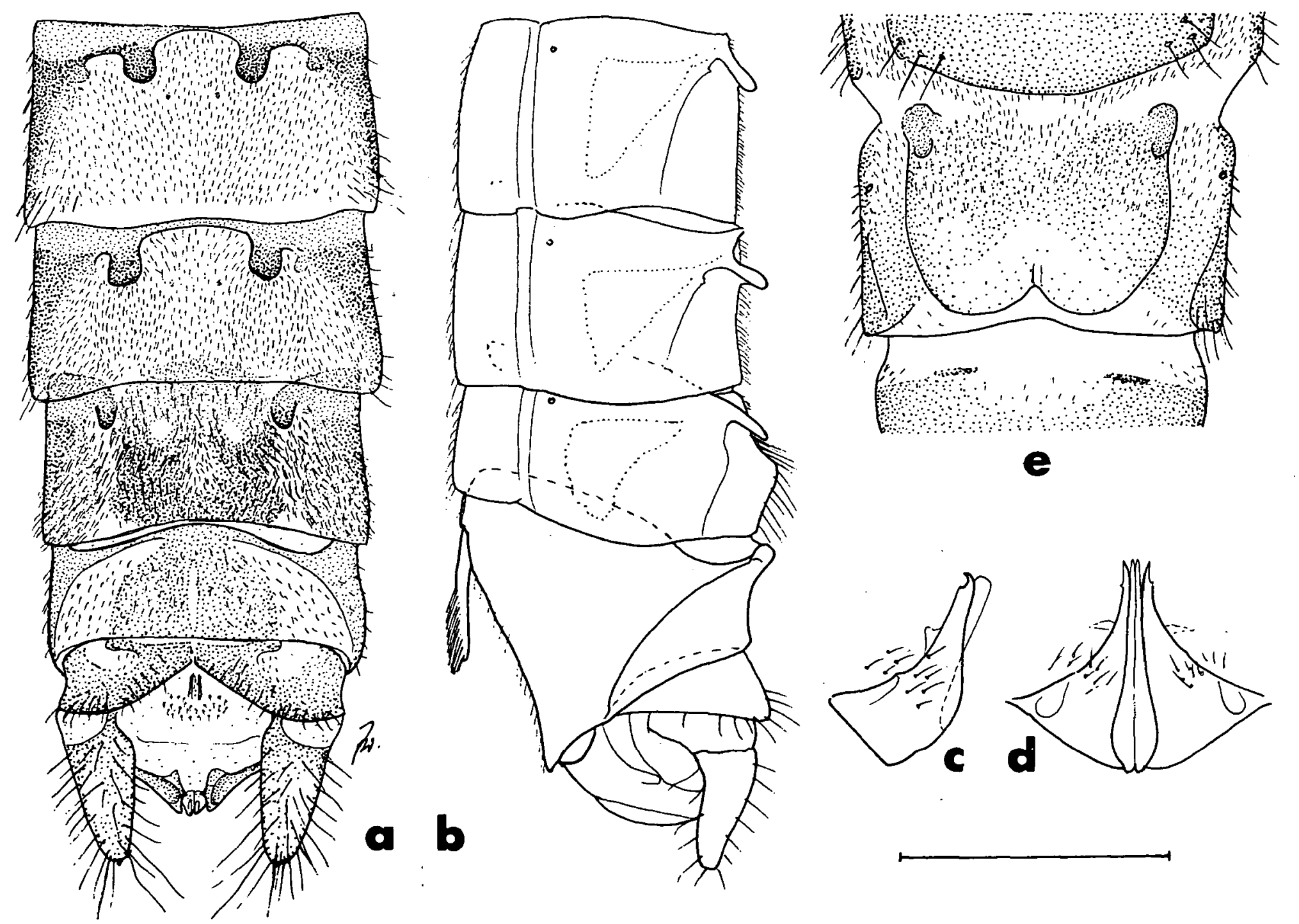

Fig. 1. Leuctra hexacanthoides : male abdominal tip in dorsal (a) and lateral (b) view ; male paraprocts in lateral (c) and posterior (e) view ; ventral view of female sternite 8 (e). The scale is $0.5 \mathrm{~mm}$, for all figures.

Fig. 1. Leuctra hexacanthoides : extrémité de l'abdomen du mâle, vue dorsale (a) et latérale (b) ; paraproctes mâles en vue latérale (c) et postérieure (d); vue ventrale du sternite 8 femelle (e); échelle de $0.5 \mathrm{~mm}$, pour toutes les figures. 
- Affinities : Close affinity with $L$. hexacantha Despax, 1940 (from the Alps and the Apennines) is evident, although distinction is easy. While processes of tergite VII arise from sides near midlength and are somewhat twisted in $L$. hexacantha (i.e., resemble $L$. fusca Linnaeus, 1758), they are situated in front and straight in $L$. hexacanthoides. Vestigial pilosity of outer paraproct lobes of the present species also indicates closes affinities with $L$. hexacantha, where these lobes are strongly setose, but completely lack tips. Females of both species are morphologically very similar; however, the subgenital plate is dark in front and pale behind in $L$. hexacanthoides, the opposite is true in L. hexacantha.

-Ecology : The species is known only from the Pyrénées-Atlantiques in France, and the province of Pamplona in Spain. It lives in streams of various sizes, at elevations between 500 and $1500 \mathrm{~m}$. Its flight period is autumnal, from August to December.

\subsection{Leuctra berthelemyi Zwick \& Vinçon sp.n.}

Material : France, Dépt. Pyrénées-Atlantiques, Vallée de la Nive de Béhérobie : Nive de Béhérobie, $900 \mathrm{~m}$, 6.8.1987 : male holotype, $11 \circ^{\circ}, 8$ \& , 4 nymphal paratypes plus $2 O^{\prime}, 10 \%$ nymph. - Additional material : Vallée du Vert d'Arète : Ruisseau de Chousse, $1100 \mathrm{~m}, 10$ ơ , 3 \%, 7.8.87; 5 o , 2 १, 20.12.92;800 m, 3 \& , 2.5.91. Vallée du Gave de Larreau : Ruisseau de Sorkatchegy, $200 \mathrm{~m}, 1$ ơ, 1 \& 6.8 .87 . Vallée du Rio Irati : tributary to Rio Iratico Erreka at location called « Sourzay », 1300 $\mathrm{m}, 3$ o , 3 ९, 6.8.87 ; 2 ९, 20.12.92 ; Ruisseau d'Esterenguibel, $1200 \mathrm{~m}, 11 \sigma^{\circ}, 5 \%, 6.8 .87 ; 4 \sigma^{\circ}, 6$ \%, 20.12.92; Ruisseau d'Inzarasquijko, $1000 \mathrm{~m}, 7 \circ^{\circ}, 7$ \%, 6.8.87. Spain, Prov. Pamplona : Vallée du Rio Urrobi : tributary to Rio Urrobi above Roncesvalles, $1300 \mathrm{~m}, 3$ o', 4 \% , 29.8.86; $6 \sigma^{*}, 3$ ᄋ, 20.12.92. Vallée de la Nive d'Arnéguy : Rio Luzane Valcarlos, $1000 \mathrm{~m}, 3$ o , 3 \& 29.8.86 ; $1 \sigma^{\circ}, 2$ \%, 20.12.92.

Micropterous, wings reach just beyond metathorax. Hind wings are small oval flaps without anal lobe, venation indistinct, except $C$ and $R$. Body length 5 - $7 \mathrm{~mm}$. Uniformly brown, aged specimens almost blackish, except whitish tergites I-VIII of females ; tergite I with light central sclerite in pale center surrounded by peripheral sclerite ; segments II-VII each with transverse row of minute dark spots, antecosta II sclerotized but medially interrupted.
- Male (Figs 2a, b) : Tergites I-V fully sclerotized, VI-IX medially membraneous. Antecosta VI entire, strong, with two almost vertically raised paramedian sclerotized points separated by about one third of the segment's width. Antecosta VII generally similar, less strong, smaller points wider apart. Antecosta VIII widely divided, a pair of small diffusely sclerotized brown paramedian spots posteriorly. Antecosta IX even more widely divided, posteriorly with a trapezoidal anteriorly notched brown spot. Tergite X medially a little notched, epiproct normal, racket-shaped. Paraprocts normal, slender, regularly and strongly curved, outer lobes shorter than median ones and more sharply pointed than these. Cerci normal, sternite IX simple, normal, vesicle with short peduncle.

- Female (Figs 2c, d) : Anterior sternites normal, sclerites progressively larger posteriorly, sternite VII separate from subgenital plate on sternite VIII. Subgenital plate strongly constricted just distally from middle, narrow distal portion separated into two transversely oval lobes by a small square notch. Basolateral portions of plate swollen, raised, with rather strong setae. Posterior lobes less strongly raised, pilosity finer, medially directed except a single rearward directed very strong seta on posterior edge near outside. Note that this seta is pale and hence less obvious in nature than it appears in Fig. 2c.

Spermatheca exceptional (Fig. 2d), consisting of the usual median extension in front of oviducal opening into vagina; however, even in mated females (receptacle filled with sperm) it is not spherical as usual but rather a rounded lobe with wide base. Armature difficult to observe even in completely sclerotized specimens. In virgins, it forms a distal re-inforcement of receptacular wall, with narrow posterior paramedian prolongations.

- Nymph : Relatively stout, thorax massive ; wing pads short ; tibiae shorter than, or equal to, very strong femora. Remarkable for complete nudity of thoracic nota, except 1 or 2 short truncate setae in front corner of pronotum. Abdomen with normal dense fine pilosity and about 6-8 setae in a transverse row barely extending to edge of segment near midlength. Femora with few prominent short truncate semi-erect setae. Cerci bare except terminal verticils of setae which are shorter than segments and comprise only very few setae on distal segments. 

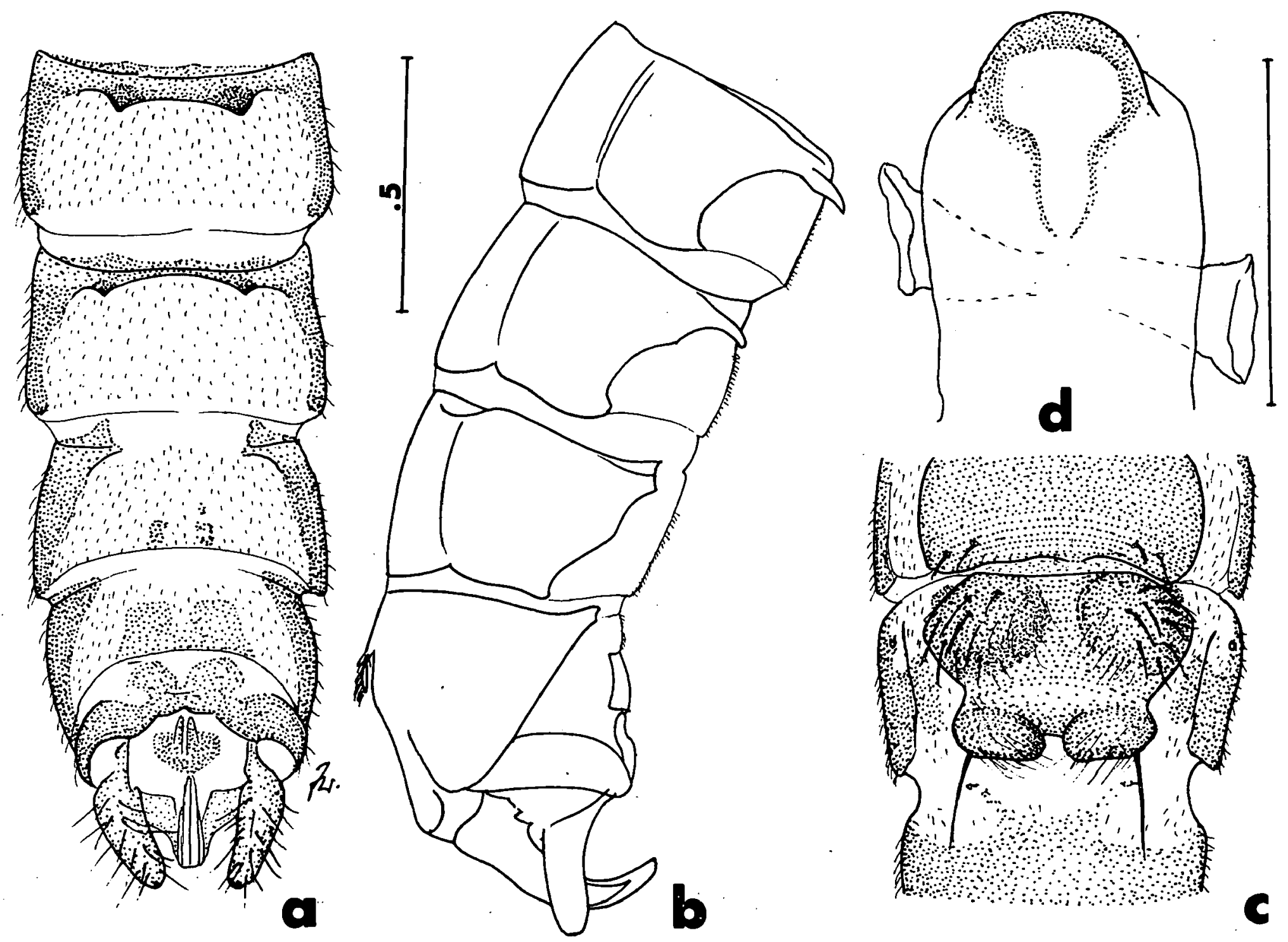

Fig. 2. Leuctra berthelemyi : Male abdominal tip in oblique antero-dorsal (a) and lateral (b) views, female sternite 8 (c) and cuticular lining of apex of vagina with receptacle and bases of oviducts (d). The scale is $0.5 \mathrm{~mm}$ for figures a-c, and $0.2 \mathrm{~mm}$ for figure d.

Fig. 2. Leuctra berthelemyi : extrémité de l'abdomen du mâle, vue oblique antéro-dorsale (a) et latérale (b) ; vue ventrale du sternite 8 femelle (c) et revêtement cuticulaire de l'apex vaginal, avec cuticulaire de l'apex vaginal, avec réceptacle et bases des oviductes ; échelle de $0.5 \mathrm{~mm}$ pour les figures a-c, $0.2 \mathrm{~mm}$ pour figure $\mathrm{d}$.

- Affinities : At first glance, paired points on male tergites remind one of $L$. braueri Kempny, 1898 , but otherwise there is no similarity between the two taxa. No similar species is known to us, the structure of the spermatheca appears to indicate a rather isolated position in Leuctra.

- Ecology : Known only from the PyrénéesAtlantiques (France) and Pamplona (Spain), like the preceding species ; of even more restricted distribution than $L$. hexacanthoides. A cold stenothermous species, inhabitant of small streams at short distances from their spring sources, between 900 and $1300 \mathrm{~m}$. The nymphs were found in leaf packs. The flight period lasts from August to May.

- Dedication : We name this species in grateful memory of the late Prof. Claude Berthélemy, for his important contributions to the study of European Plecoptera, not least the Leuctridae. He has been supervisor of one of us (G.V.), and a friendly colleague whom we have admired for his careful observations and well-considered opinions on structure, function and phyletic affinities of the Plecoptera.

\subsection{Leuctra thomasi Zwick \& Vinçon sp.n.}

Material : Andorra, Coma Pedrosa, $2300 \mathrm{~m}$, 14.7.1986, male holotype, 9 \%, 10 \% paratypes. - Additional material : Andorra : Haute Vallée du Sègre, Ruisseau de la Coma Pedrosa, 2700 m, 4 \& , 1 nymph, 9.8.86 ; $2550 \mathrm{~m}, 21 \odot^{*}, 15$ \%, 14.7.86. France, Dépt. Ariège : Vallée de l'Ariège : Tributary of Ruisseau d'Estatz at a place called «Bazurs », $1800 \mathrm{~m}, 1$ ᄋ , 12.7.86 Ruisseau d'Estatz, $1800 \mathrm{~m}, 1 \%$, 1 \%, 12.7 .86 ; tributary of 
Ruisseau d'Arties, near lake Orry de la Caudière, $1900 \mathrm{~m}$, 1 Q , 25.8.91. Vallée du Salat : Ruisseau de Garbet, near lake Etang Bleu, 2100 m, 2 \&, 24.8.91.

Fully winged, wing length $5-7 \mathrm{~mm}$. Pronotum as wideas ong, or a little wider. Uniformly brown, except female abdomen pale and patterned as in preceding species.

- Male (Fig. 3a) : Antecosta VII narrowly divided, median strip of segment poorly sclerotized, pale, limits of lateral sclerites diffuse. Antecosta VIII largely hidden under segment VII, widely divided, ends curved back and appearing as very small, almost seta-like rearward points. Median strip of tergite VIII pale, soft, flanked by parallel edges of sclerites terminating in small narrow points resting on dorsum. Posterior portion of tergite laterally from each point less sclerotized than front portion. Antecosta IX widely divided, pointed ends directed medially ; sclerotization Iargely restricted to sides of segment, but forming well defined lateral lobes behind the antecosta. Pale center of tergite IX with deeply divided brown patch. Posterior edge of tergite $\mathrm{X}$ deeply notched, receiving wide pentagonal epiproct whose middle is raised in a blunt keel. Paraprocts long and slender, regularly curved. Curvature of outer and inner lobes similar, both simply pointed, but outer lobes shorter, ending distinctly below tips of inner ones. Sternite IX with normal pedunculate, distally setose vesicle.

- Female (Figs 3b-e) : Sternite VIII forming a gently curved subgenital plate with a median small point near midlength and two short transverse distal lobes (Fig. 3b). Lobes bent down to ventral side, outer edges more so than median portion, upper face of lobes exposed in side view (Fig. 3c). Lobes broader than anterior portion of plate. Posterior edge of lobes directed obliquely to outside, straight,
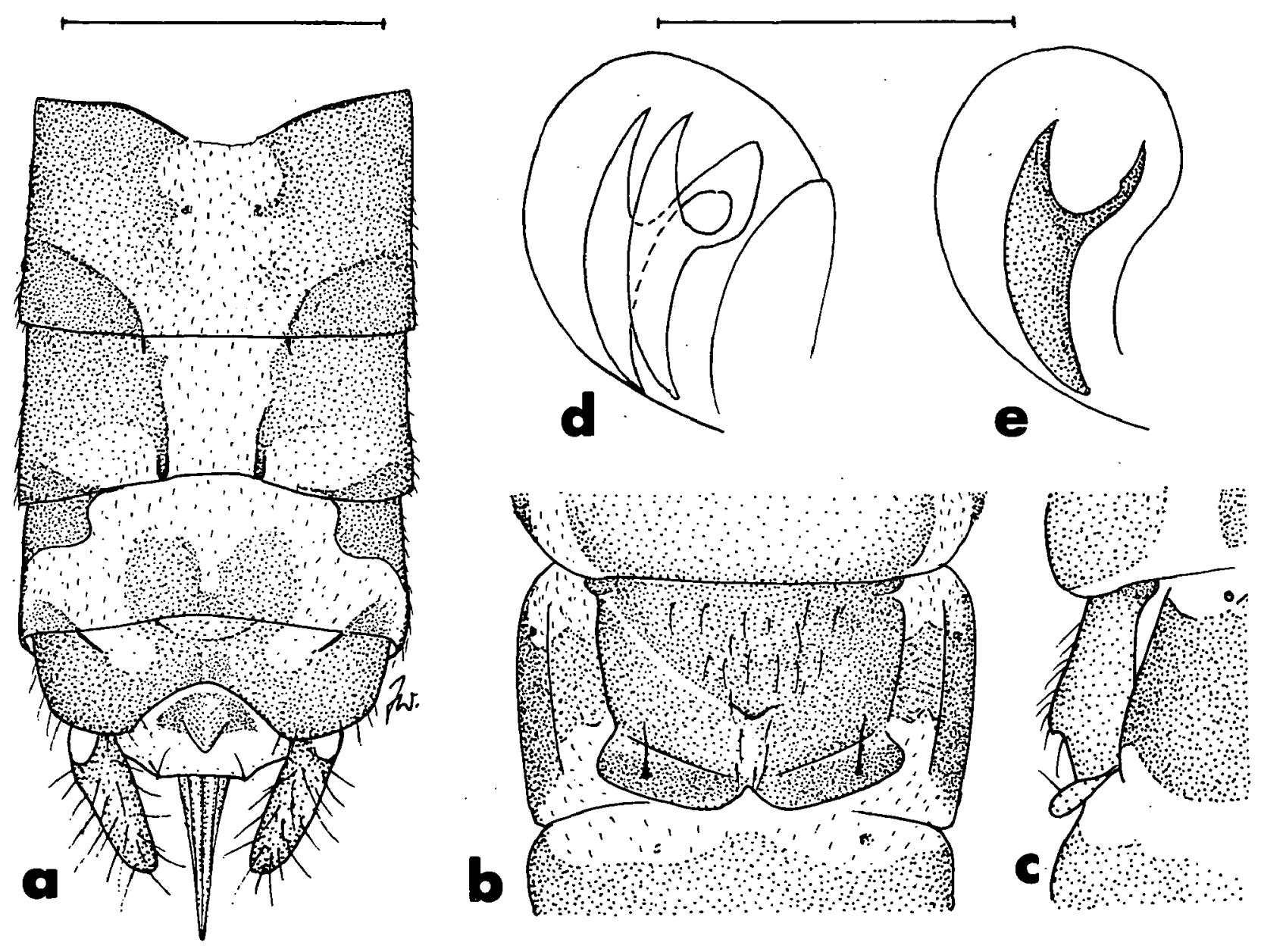

Fig. 3. Leuctra thomasi : Male abdominal tip in dorsal view (a), sternite 8 of female in ventral (b) and lateral (c) views, seminal receptacle and its sclerite (somewhat diagrammatic) in oblique ventrolateral (d) and lateral (e ; ventral half is on left side) views. The $0.5 \mathrm{~mm}$ scale applies to Figs a-c, the $\mathbf{0 . 2} \mathrm{mm}$ scale to Figs $\mathrm{d}$ and $\mathrm{e}$.

Fig. 3. Leuctra thomasi : extrémité de l'abdomen du mâle, vue dorsale (a), sternite 8 de la femelle en vue ventrale (b) et latérale (c), réceptacle et ses sclérites (un peu schématique) en vue oblique ventro-latérale (d) et latérale (e). L'échelle de $0.5 \mathrm{~mm}$ s'applique aux figures a-c, celle de $0.2 \mathrm{~mm}$ aux figures $d$, e. 
curved forward only medially, creating a small notch between the two lobes. Each lobe carries a strong (but pale and hence easily overlooked) large erect seta. Seminal receptacle normal, spheroid, sclerite of typical form : a narrow dorsomedian ring expanding laterally into elongate siccle-shaped sclerites forming short anterior and long posterior arms (Figs $3 d, e)$.

- Affinities : Evident relative of the Moroccan $L$. vaillanti Aubert, 1956. Males of $L$. thomasi differ by divided antecosta VII, posteriorly (instead of medially) directed ends of antecosta VIII, sclerotized lobe behind antecosta IX (sclerites are simply narrowed, conical in $L$. vaillanti), and by presence of a vesicle. General structure of females seems to be similar, although Aubert's figures (but not his text !) suggest the relatively larger posterior lobes of $L$. vaillanti may be swollen, cushion-like ; this may be an artefact during $\mathrm{KOH}$-treatment of his specimens. The generally medially convergent posterior margin of the lobes of subgenital plate and lack of the median tubercle on the plate are obvious specific differences. The female subgenital plate, especially its tubercle, and also the male tergites are reminiscent of several species of the $L$. primacomplex in the $L$. hippopus-group, the male reminding most of $L$. sesvenna Aubert, 1953.

- Ecology : Known only from Ariège (France) and Andorra. A cold stenothermous species restricted to very high altitudes, between 1800 and $2700 \mathrm{~m}$. On the Coma Pedrosa, it is most abundant at $2550 \mathrm{~m}$; it seems to prefer slightly higher altitudes than $L$. alticola Despax, 1929, which has not been found above $2550 \mathrm{~m}$, in this valley. The flight period is in summer, from July to August.

- Dedication : We have pleasure dedicating this species to our friend, Dr. Alain Thomas, Maître Assistant at the Université Paul Sabatier of Toulouse for his important contributions to the study of European Ephemeroptera and Diptera ; he found the first male of this interesting species on the Coma Pedrosa, Andorra, in 1972.

\subsection{Protonemura culmenis Zwick \& Vinçon sp.n.}

Material : Andorra : Haute Vallée du Sègre, Ruisseau de la Coma Pedrosa, $2700 \mathrm{~m}$, male holotype, 9.8.1986 ; the following adults are paratypes : same locality, $2 \sigma^{\circ}$, 14.7.86 and $22 \sigma^{\circ}, 8$ \%, 6 nymphs, 9.8.86. - Additional material : Andorra : Coma Pedrosa, $2550 \mathrm{~m}$,
$3 \sigma^{*}, 3$ \% 14.7.86. France, Ariège : Vallée de l'Ariège : Ruisseau d'Estatz, 2000 m, 1 male nymph, 7.7.81 (Brouquet leg).

Of moderate size, front wing 6.5 . - $10.0 \mathrm{~mm}$ long. Sclerotized body portions dark brown ; in juvenile specimens, posterior part of head behind coronal suture sometimes reddish. Antennae blackish. Legs yellowish brown, with infuscate bases of tibiae and tarsi. Dark longitudinal lines along anterior and posterior edges and a shorter middorsal line on each femur. Wings slightly infuscate. Six very short and thin cervical gills, as long and as wide as the basal tarsal segment. Abdomen unsclerotized in females, except posterior portion of segment IX and all of segment X. In males, tergites sclerotized ; sclerotization of sternites reduced to a pair of anterior little sclerites on each segment.

- Male (Figs 4a-c) : Tergite IX with median soft area flanked by two important groups of strong black spines. Sternite IX normal, i.e., basally with well developed parallel vesicle, distally extended into a subgenital plate. Tergite $\mathrm{X}$ with central soft area below tip of epiproct, no spines.

Epiproct rising from usual pouch, curved forward. Essentially soft and pale in dorsal view, rounded, medially split tip. Greatest width about one third from apex, gently narrowed anteriorly and more strongly restricted towards base. In side view, apex of epiproct much wider than slender parallel sclerotized base. Ventral sclerite supporting a strong rounded median projection with many short spines ; projection situated below highest point of epiproct. Dorsal sclerite ending about one third from tip, except for a very narrow strip-like sclerite extending further towards apex and supporting soft pale membrane forming rounded, very gently upcurved apex of epiproct. A half-moon-shaped sclerite inside apex visible by transparency; its tip projecting a little above epiproct membrane.

Cerci simple. Paraprocts very complex, small blade-like inner lobes (terminology of Baumann, 1975) hidden under extension of subgenital plate, as usual. Large median lobes consisting of a paramedian finger-like process (ending in a sharp spine) basally on outside connected to large subanal lobe. Sclerotized portion of subanal lobe ending in a small triangular point in ventral view ; in lateral view, upper edge rounded and not well delimited against membraneous apex. Membrane at apex, above tip 

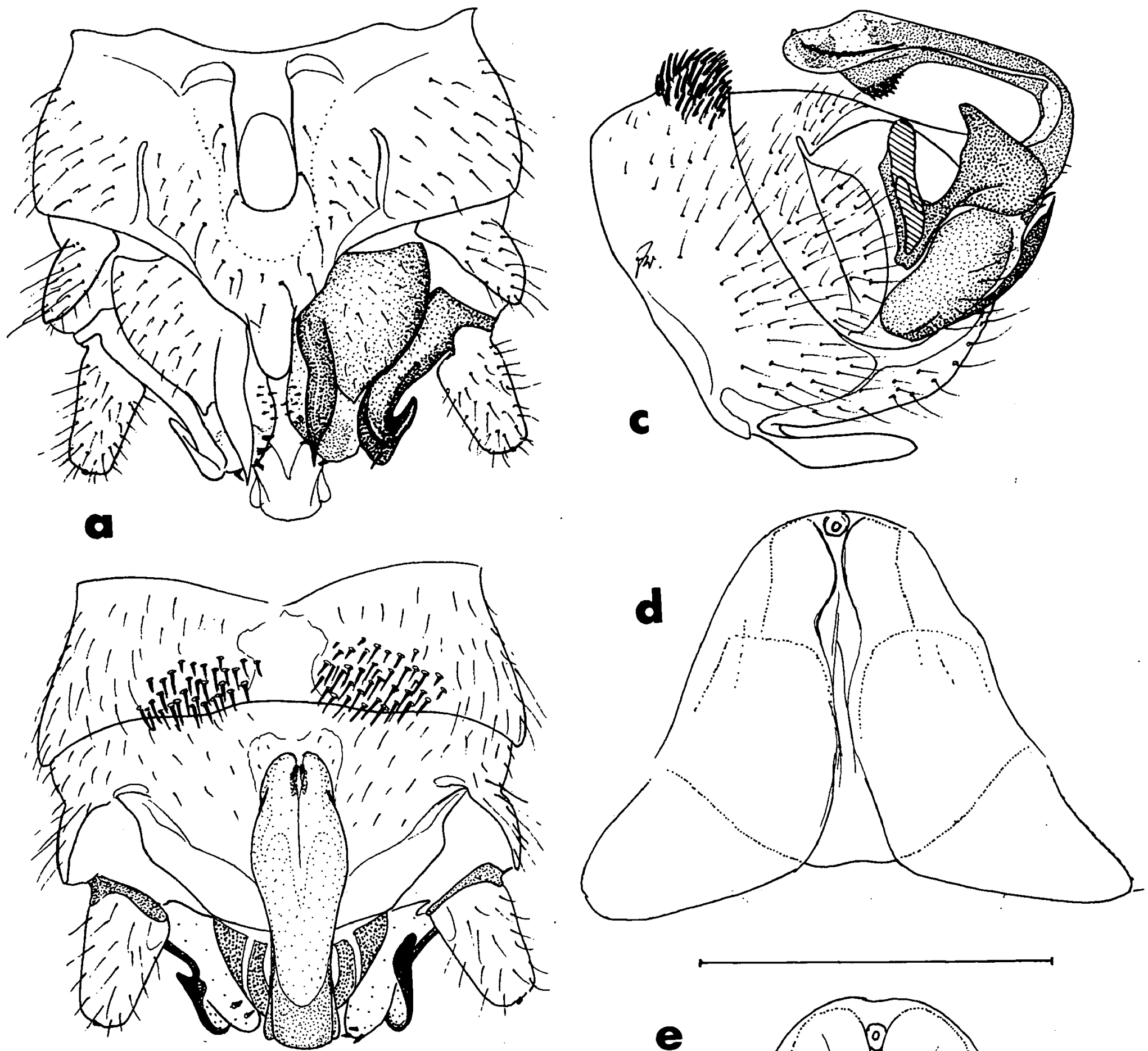

b

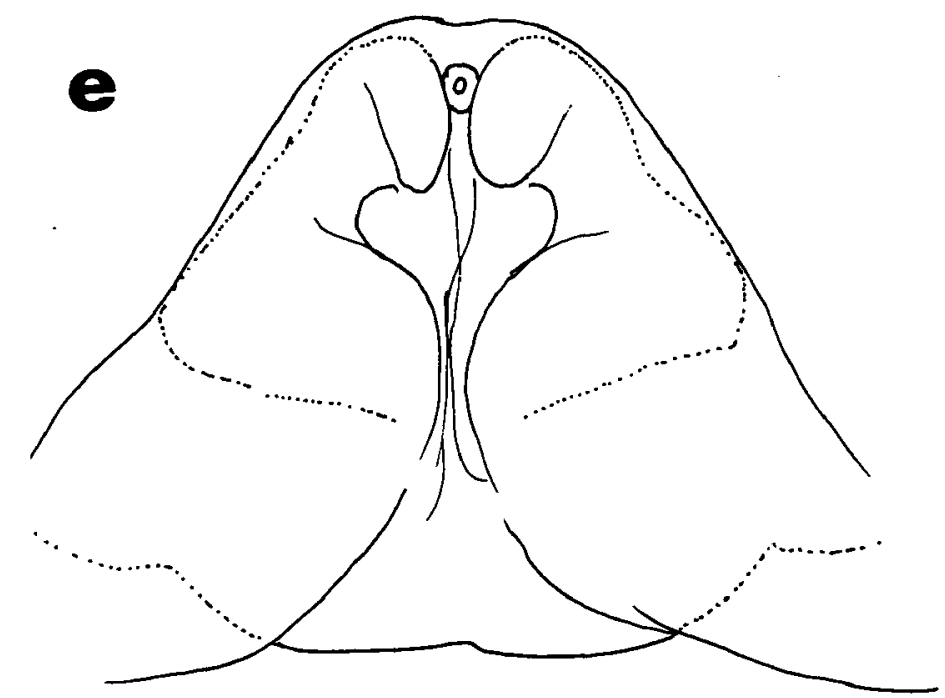

Fig. 4. Protonemura culmenis : Male abdominal tip in dorsal (a), ventral (b) and lateral views (c) ; female vaginal complex, dorsal view, slightly diagrammatic (d). Protonemura tuberculata, female vaginal complex, dorsal view, slightly diagrammatic (e). The scale (figures $\mathrm{d}$, e only) is $0.5 \mathrm{~mm}$.

Fig. 4. Protonemura culmenis : extrémité de l'abdomen du mâle, vue dorsale (a), ventrale (b) et latérale (c) ; femelle, vue dorsale du complexe vaginal, légèrement schématique (d). Protonemura tuberculata, femelle, vue dorsale du complexe vaginal, légèrement schématisé (e). Echelle de $0.5 \mathrm{~mm}$ (seulement figures d, e). 
of finger-shaped appendage, vaguely sclerotized, with a number of short strong spines. Outer paraproct lobe strong, sclerotized, leaning against median lobe. Apex of sclerite strongly enlarged, truncate, anterior edge pointed, the much wider posterior edge strongly rounded, hook shaped in ventral aspect.

- Female (Fig. 4d) : a small pigmented pregenital plate at the end of sternite VII. Sternite VIII with a dark tongue-shaped subgenital plate, a little bilobed at tip, depressed along midline and raised on sides, extending as far as, or a little beyond, exposed transverse pale vaginal lobes. Inner structure simple, vaginal sclerotization forming a flat, anteriorly truncate funnel ; no transverse folds or recurving sclerites.

- Nymph : Ochre, sand-coloured, shape typical. Pronotal setae short and dense, each widest in middle and narrowed towards base and tip, like in $P$. auberti Illies, 1954. Cervical gills not hanging down as in most other species, but spreading radially from points of insertion. Lateral gills exposed in dorsal view, much longer than both inner gills which are thin and unusually short, shorter than width of fore trochanter. Paired abdominal setae present, short, inconspicuous. Cerci missing.

- Affinities and distinction : P. culmenis is a close relative of $P$. tuberculata (Despax 1929), which, however, is a remarkably pale species. The main structural differences are as follows :

- Male : $P$. tuberculata has a simple triangular subanal plate ending in a tip, while it is rather blunt in $P$. 'culmenis and has a separate, paramedian finger-shaped appendage instead. Posterior contour of outer paraproct sclerite forming a right angle with straight sides in $P$. tuberculata, no large posterior extension like in $P$. culmenis. Epiproct of $P$. tuberculata with much stronger, tooth-shaped ventral process ; tip of epiproct in dorsal view distinctly narrower so that normally the apex of its basal plate is laterally exposed.

- Female : distinguished from $P$. tuberculata by dark colour and extremely short and narrow gills. Genitalia externally similar to $P$. tuberculata which, however, lacks distinct pregenital sclerotization. Inner vaginal sclerites of $P$. tuberculata shorter, more abruptly narrowed and further distinguished by strong transverse recurving apical folds (Fig. 4e).
- Nymph : Although a full description of nymphs is postponed until a comparative study of Pyrenean Protonemura, the extremely short gills of $P$. culmenis appear to be distinctive. Anterior pronotal setae of $P$. tuberculata distinctly longer, less constricted basally ; a full description of the latter species was provided by Berthélemy (1982).

- Ecology : Known only from Ariège (France) and Andorra. Restricted to very high altitudes from $2000-2700 \mathrm{~m}$ (hence the specific name which is derived from lat. culmen, summit), cold stenothermous. The adults were found under stones along streams. In the Coma Pedrosa, at $2700 \mathrm{~m}$, only $P$. culmenis was found ; at $2550 \mathrm{~m}$ it coexisted with (the more abundant) $P$. tuberculata, while only the latter was found at $2400 \mathrm{~m}$ and below. Flight period : summer, from July to August.

\subsection{Protonemura canigolensis Zwick \& Vinçon sp.n.}

Material : France, Dépt. Pyrénées-Orientales : Vallée de la Têt : Mt. Canigou, Rivière Llitera, near its spring source, $1900 \mathrm{~m}, 17.9 .1988$, male holotype, 8 o , 5 . . paratypes, 6 nymphs ; brooklet tributary to Lentilla river at Los Masos, $1050 \mathrm{~m}, 5$ \&, 23.12.92.

Shape typical ; macropterous, front wings 7-10 mm. Gills simple, short, no apical constriction. Generally brown; head with triangular yellow marks between compound eye and lateral ocellus. Antennae brown; legs yellowish, with darker stripes on femora, infuscate ends of tibiae, infuscate tarsi, as usual. Abdomen pale, soft except well sclerotized terminal segments.

- Male (Fig. 5a-c) : Sternite IX normal, basally with pedunculate vesicle, distally extended into a subgenital plate. Tergite IX bilobed, lobes raised, beset with many peg-like straight sensory setae. A few similar setae posterolaterally on tergite $X$; antero-medially, tergite $\mathrm{X}$ has a rounded membraneous area below epiproct tip. Epiproct with distinct, comma-shaped terminal filament bending down and to the right side. Epiproct slender, parallel except the usual constriction of basal sclerites. Epiproct flat in side view, with shallow dorsal hump in middle of membraneous section. Lateral sclerites thin, thread-like, almost straight. Ventral sclerites hardly projecting, setation sparse, short, pale, inconspicuous. 

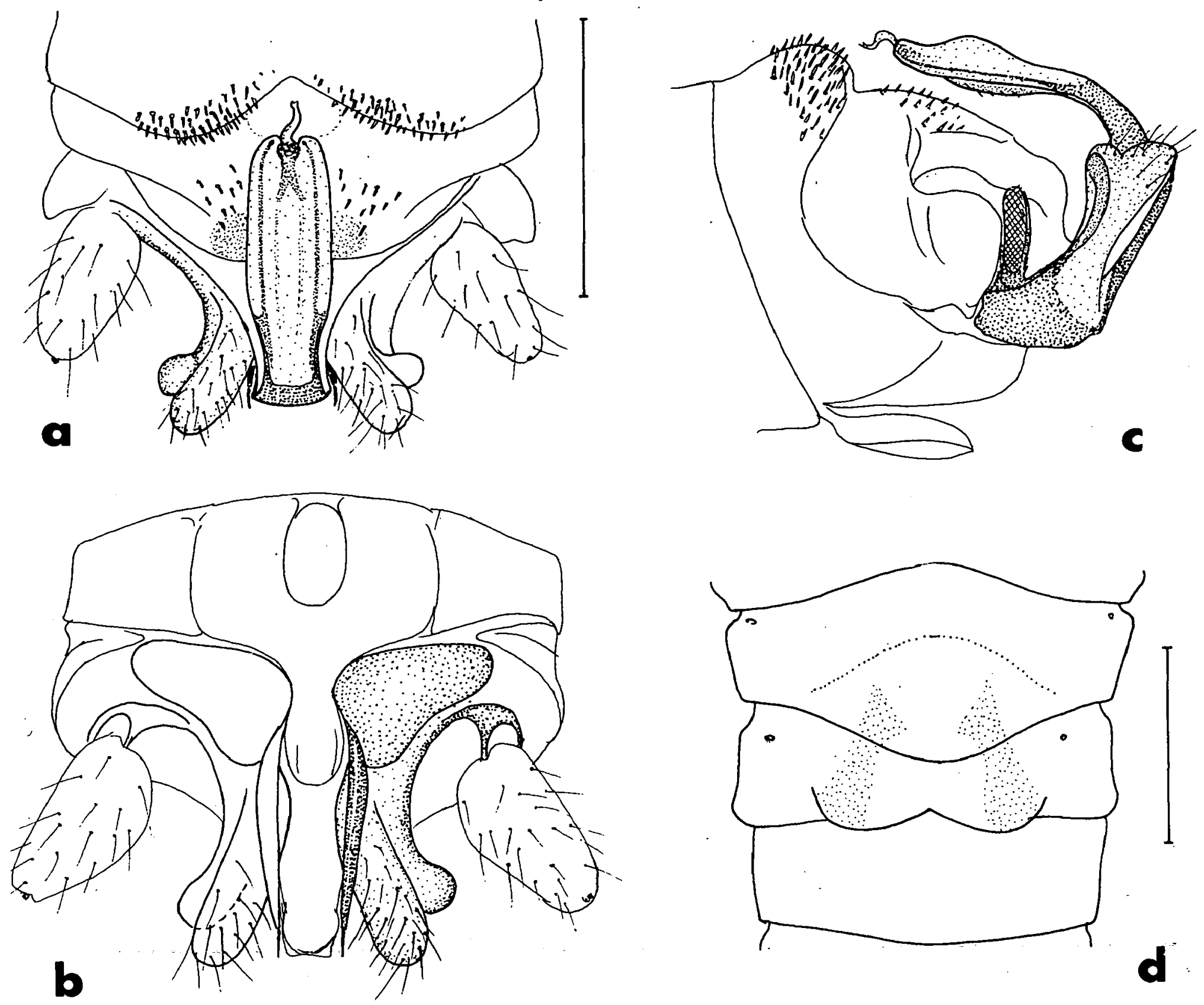

Fig. 5. Protonemura canigolensis : Male abdominal tip in dorsal (a), postero-ventral (b) and lateral (c ; cross hatching identifies attachment site of cercus, which has been removed) views ; female genital region, ventral view (d). Scale lines are $0.5 \mathrm{~mm}$; same scale for figures a-c.

Fig. 5. Protonemura canigolensis : extrémité de l'abdomen du mâle, vue dorsale (a), ventrale (b) et latérale (c) ; région génitale femelle, vue ventrale (d). Echelles de $0.5 \mathrm{~mm}$; même échelle pour les figures a-c.

Paraprocts : Inner lobes normal, blade shaped, hidden by subgenital plate. Median lobe approximately triangular, with rounded edges, mediodistally connected to a long slender blade with straight terminal spine flanking base of epiproct. Blade gently curved in ventral view, almost straight in side view. Outer lobe of paraproct long, straight, tubular, pilose. Its outside and front supported by band-shaped cercus sclerite curving towards middle ; it is gently twisted so that its projecting sclerotized end faces forward. In dorsal or ventral views, cercus sclerite distinctly shorter than outer lobe ; in late- ral view, both rise to about same level, appearing like a bifid apex. Cerci simple.

- Female (Fig. 5d) : Sternite VII a large pale pregenital plate, more shining than rest of segment. Sternite VIII ending in a flat bilobed subgenital plate projecting slightly beyond segment edge, and completely covering vaginal lobes. Subgenital plate pale, fleshy white even in old specimens where general sternal cuticle of abdomen becomes speckled with small brownish sclerotized spots around hair insertions. In such old females, dark bands inside copulatory pouch originating from the hidden vaginal lobes are visible by transparency. 
- Nymph : Typical of genus, stout. Six gills simple, short, not constricted, each about same length as front coxa. Light brown, tegument remarkably shiny, despite presence of numerous setae. Fully developed wing pads somewhat mottled in brown and pale, much like in $P$. meyeri (Pictet). Setal fringe of pronotum dense, setae long, slender ; anterolateral setae almost as long as antennal pedicle in dorsal view. Abdominal tergites with dense setation on surface ; setae along wide median portion of distal margin hardly longer. Laterally, margins with groups of distinctly longer setae amidst which the paired abdominal setae (about one third the segment's length) are not very conspicuous. Cerci short, but nevertheless already segment VII as long as wide. Setal verticils short, never quite half as long as corresponding segment. Beyond segment XI or XII, setal fringes become incomplete on dorsal side ; on distal segments, only 1 to 3 ventral setae of about two fifth of segment length.

- Affinities and distinctions : The conspicuous terminal filament of epiproct places $P$. canigolensis into the group of $\boldsymbol{P}$. corsicana Morton. Future research will have to confirm monophyly of the corsicana-group based on this single epiproct character. In $P$. canigolensis, other genital characters are in line with this group membership, although details of structure differ specifically. Identification by the peculiar curved epiproct filament is particularly easy ; in all other species of the group it is straight, symmetrical. $P$. canigolensis is, however, not unique in this respect : curved asymmetrical terminal filaments of epiproct occur in other nemourid genera, e.g. the sometimes miraculously long and complex structures of Asian Mesonemoura and Indonemoura. Complete coverage of vaginal lobes and large size of pregenital plate of females are also distinctive.

- Ecology : P. canigolensis is known only from Mont Canigou, Pyrénées-Orientales (France), from which the specific name is derived. It has been found in two brooklets near their spings, at high altitudes between 1050 and $1900 \mathrm{~m}$; the species is cold stenothermous. It flies in autumn, from September to December.

$P$. canigolensis is the only Protonemura in Spain or the Pyrenees belonging to the corsicana group. This group is widespread in the Mediterranean area (Zwick 1978), its western representatives have a
Tyrrhenian distribution. In this context it is interesting to note that Mont Canigou is at the eastern border of the Pyrenees, at a short distance from the Mediterranean Sea.

\subsection{Protonemura montana Kimmins, 1941}

Material : France, Dépt. Pyrénées-Orientales : Vallée de la Têt, Massif du Canigou : tributary of Cady r., 1900 $\mathrm{m}, 10^{\circ}, 3$ nymphs, 17.9 .88 ; Llitera river, $1900 \mathrm{~m}$, 1 \& , 17.9 .88 ; brooklet, tributary to lentilla river at Los Masos, $1050 \mathrm{~m}, 2$ \& , 27.8.91. Vallée du Sègre, Ruisseau d'Err, $2250 \mathrm{~m}, 1$ \& 16.9 .88 . Vallée de l'Ariège : tributary of Ariège river, before Pas de la Case : $1900 \mathrm{~m}, 22$ $\sigma^{\circ}, 21$ \%, 22.8.1988; $6 \sigma^{\circ}, 4$ \%, 16.9.88; $2 \sigma^{\circ}, 26.8 .91$; $2200 \mathrm{~m}: 6$ ơ, 2 ९, 3 nymphs, $22.8 .88 ; 1$ ○', 1 \%, 26.8.91.

The present specimens resemble Czech (Krkonose, above Harrachov), Polish (Tatra Mts near Zakopane) and Romanian (Transsylvanian Alps, Buda valley) specimens. $P$. montana has a disjunct distribution. Its eastern range centers in the Carpathian mountains from where it extends, via the Tatra Mts in the northwest, into Thüringen (Zwick 1973), Bavaria (Mendl 1968, Schulte \& Weinzierl 1990) and the Austrian Böhmerwald (Theischinger 1976) ; in the southeast, it reaches Bulgaria (Braasch \& Joost 1971) and Makedonia (e.g., Ikonomov 1986).

For a long time, the western range included only the British Isles (from where the species was first described), until $P$. montana was found in the French Massif Central (Aubert 1963a) and the Vosges (1963b): Its discovery in the Pyrenees is not out of line of this general distribution but is a surprize in view of the presence of close relatives, especially $\boldsymbol{P}$. beatensis Despax and its group (Berthélemy 1963). One of these endemic Pyrenean species, $P$. angelieri Berthélemy, 1951, has an Alpine counterpart, $P$. algovia Mendl, 1968. All species mentioned fly in autumn. $P$. montana is only found in the eastern part of the Pyrenean mountain range where it lives in high altitude brooks, near their spring sources.

\subsection{Protonemura brevistyla (Ris, 1902)}

Material : France, Pyrénées-Orientales : Vallée de la Têt : spring source tributaries of Ruisseau d'Eyne, $2200 \mathrm{~m}, 40^{\circ}, 4$ \%, 28.7.87. Vallée du Sègre : Ruisseau d'Err, $2250 \mathrm{~m}, 90 \sigma^{\circ}, 60 \%$ and 6 nymphs, 27.8 .86 (of which $150^{\circ}, 15 \circ$ and 3 nymphs in coll. Zwick). HauteGaronne : brooklet, tributary of Pique river, before Port de Venasque, $2100 \mathrm{~m}, 1$ O*, 22.10.89. Spain, Prov. 
Gerona : tributary of Rio Duràn, 2000 m, 1 o , 7.7.87. Prov. Huesca, Vallée du Rio Noguera Ribagorzana, tributary of Rio Salenques, 2000 m, 1 \&, 11.9.86.

The discovery of this species in the Pyrenees is a surprize. $P$. brevistyla has a Carpathian and Alpine distribution, with marginal introgression into adjacent mountain ranges of Upper Austria (Theischinger \& Humpesch 1967) and into the Bavarian Forest (Schulte \& Weinzierl 1990). It is not known from the French Massif Central.

The complex male genitalia of Alpine and Pyrenean specimens agree. Females are also similar, but they are on the whole less distinctive. Still, at first glance, Pyrenean specimens look different because most are somewhat brachypterous. In females, wings reach the tip of abdomen, or extend even a little beyond it. In several males from the Ruisseau d'Err, the tip of abdomen is exposed and in those from the Ruisseau d'Eyne, even only the front half of abdomen is covered by the wings. The female from Rio Duràn is macropterous.

In the Pyrenees, the species was only collected at extremely high stations, near permanently cool water courses.

\section{Acknowledgements}

We express our gratitude to Dr. Yves Brouquet (Toulouse) who found the first specimen of Protonemura culmenis. Dr. C. Ravizza (Milano) is thanked for helpful information.

\section{References}

Aubert J. 1963a. - Contribution à l'étude des Plécoptères du Massif Central. Bull. Soc. ent. France, 68 : 163-185.

Aubert J. 1963b. - Les Plécoptères des Vosges. Le Hohneck : 287-292.
Baumann R.W. 1975 - Revision of the stonefly family Nemouridae (Plecoptera) : A study of the world fauna at the generic level. Smiths. Contribs Zool., $211: 74$ pp.

Berthélemy C. 1963. - Les Protonemura (Plécoptères) automnales des Pyrénées. Bull. Soc. Hist. nat. Toulouse, 98 : 275-286.

Berthélemy C. 1966. - Recherches écologiques et biogéographiques sur les Plécoptères et Coléoptères d'eau courante (Hydraena et Elminthidae) des Pyrénées. Annls Limnol., 2 : 227-458.

Berthélemy C. 1982. - Sur deux Protonemura endémiques des Pyrénées (Plecoptera : Nemouridae). Annls Limnol., 17 (1981) : 243-249.

Braasch D. \& Joost W. 1971. - Zur Plecopterenfauna Bulgariens. Limnologica, 8 : 265-294.

Despax R. 1951. - Plécoptères. Faune de France, 55, 280 p.

Ikonomov P. 1986. - Plécoptères de Macédoine (Insecta, Plecoptera) Taxonomie et Distribution. Acta Mus. maced. Sci. nat., 18 (4/150) : 81-124 (in Macedonian, French summary).

Mendl H. 1968. - Steinfliegen aus Bayern - neu für Deutschland (Insecta - Plecoptera). Bayerische Tierwelt, 1 : 97-114.

Schulte H. \& Weinzierl A. 1990. - Beiträge zur Faunistik einiger Wasserinsektenordnungen (Ephemeroptera, Plecoptera, Coleoptera, Trichoptera) in Niederbayern. Lauterbornia, 6 : $1-83$.

Theischinger G. 1976. - Bestätigung von Protonemura algovia und Erstnachweis von Protonemura montana für Österreich. Linzer biol. Beitr., 8 : 389-392.

Theischinger G. \& Humpesch U. 1976. - Plecoptera (Insecta) aus Oberösterreich, II. Zusammenfassender Beitrag zur Kenntnis der Landesfauna. Naturk. Jahrb. Stadt Linz, 21 : 81-134.

Vinçon G. 1987. - Etude hydrobiologique de la vallée d'Ossau (Pyrénées-Atlantiques). II. Le milieu et la structure du peuplement benthique. Annls Limnol., 23 : 225-243.

Zwick P. 1973. - Insecta Plecoptera. Phylogenetisches System und Katalog. Das Tierreich, 94 : I-XXXII, 1-465.

Zwick P. 1978. - Steinfliegen (Insecta, Plecoptera) aus Griechenland und benachbarten Ländern. Mitt. Schweiz. ent. Ges., 51 : 21-38, 213-239. 